\title{
Dengue and Laboratory Tests a Clinician Should Know for a Correct Diagnosis
}

\author{
Subhash C. Arya and Nirmala Agarwal \\ Sant Parmanand Hospital; 18 Alipore Road, Delhi-110054, India; E-mail: subhashi@ hotmail.com
}

De Paula and Lopez da Fonseca [1] meticulously reviewed different laboratory tests that would assist a clinician towards an accurate diagnosis and care of patients afflicted with dengue. Recent commercial availability of an immunochromatographic test is also be an asset for any clinician. Marketed by PanBio, Brisbane, the Dengue Duo Rapid Strip test incorporates recombinant antigens, with which it is possible to rapidly detect dengue IgM and IgG [2]. Since recombinant proteins are used, rather than whole virus, dengue diagnostic strips overcome safety issues associated with the use of whole virus by organizations lacking trained personnel and equipped laboratory infrastructures.

Molecular investigations to characterize viral genomes are useful for fundamental studies at academic health institutions, while simple, 1-2 step tests that can be carried out in local clinics would interest doctors in private practice. Nongovernmental organizations involved in health care, along with private providers, often have a large and prominent role in many countries. Private health care workers are available in places that the public sector would find difficult to reach [2]. That would appear to be the case in Brazil. During 2001, the per capita expenditure on health was \$573, with the government share being only $\$ 238$ [3]. Academic and national control organizations would need to monitor the quality of any imported or locally-made dengue diagnostic kits. All of them basically involve an antigen-antibody reaction and like any immunology test require observance of optimal storage and assay measures.

During the $21^{\text {st }}$ century, there appears to have been a preference for using anti-dengue virus-specific IgM assays, along with virological characterizations [5]. As several dengue virus strains in simultaneous circulation in a community is not an unusual event, re-infections with a prior serotype would be associated with a dominant, earlier anti-IgG response, while the IgM response can be delayed and mild. There may be patients with secondary infection with no detectable IgM antibodies [6]. Clinicians have reported patients with central nervous system and hepatic involvements with fatal outcome [7]. Molecular investigations using in-situ PCR on preserved postmortem tissues would be informative. Dengue virus infection can be detected in paraffin-embedded autopsy tissues that have been stored for five years [8]. The same principle could be employed with molecular hybridization or RT-PCR [1] for diagnosing dengue viral infection and for studying the pathogenesis of dengue hemorrhagic fever or extensive central nervous system involvements.

\section{Acknowledgement}

The secretarial assistance of Ms. Kiran Bhatt and Ms. Sarita Kumar is acknowledged.

\section{References}

1. De Paula S.O., Lopes da Fonseca B.A. Dengue: A review of the laboratory tests a clinician must know to achieve a correct diagnosis. Braz J Infect Dis 2004;8:390-8.

2. Cuzzubbo A.J., Endy T.P., Nisalak A., et al. Use of recombinant envelope proteins for serological diagnosis of Dengue virus infection in an immunochromatographic assay. Clin Diagn Lab Immunol 2001;8:1150-5.

3. The World Health Report 2003: Shaping the future. World Health Organization: Geneva. 2003: 113. pp.

4. The World Health Report 2003: Shaping the future. World Health Organization: Geneva. 2003: Annex 6.

5. Cisneros-Solano A., Moreno-Altaminrano M.M.B., Martßnez-Soriano U., et al. Seroepidemiological and virological investigations of dengue infection in Oaxaca, Mexico during 2000-2001. Dengue Bulletin 2004;28:28-33.

6. Lam S.K., Devi S., Pang T. Detection of specific IgM in dengue infections. Southeast Asian J Trop Med Public Health 1987;18:532-8.

7. Nogueira R.M.R., Filipps A.M.B., Coelho J.M.O., et al. Dengue virus infection of the central nervous system (CNS), a case report from Brazil. Southeast Asian J Trop Med Public Health 2002;33:68-71.

8. Kangwanpong D., Bhamarapravati N., Lucia H.L. Diagnosing dengue virus infection in archived autopsy tissues by means of the in situ PCR method: a case report. Clin Diagn Virol 1995;3(2):165-72. 